\title{
The meiofauna asssociated whith Sargassum cymosum at Lázaro Beach, Ubatuba, São Paulo
}

\author{
Rita R. Curvelo* \& Thaïs N. Corbisier \\ Instituto Oceanográfico da Universidade de São Paulo \\ (Caixa Postal 66149, 05315-970 São Paulo, SP, Brasil) \\ *e-mail: curvelo@usp.br
}

- Abstract: In this study, the meiofauna associated with Sargassum cymosum was qualitatively and quantitatively analyzed between December 1990 and July 1991. Sampling was carried out on a moderately exposed shore at Lázaro Beach, Ubatuba $\left(32^{\circ} \mathrm{S}-45^{\circ} \mathrm{W}\right)$. Each alga was washed in a formaldehyde solution and the fauna in suspension was washed through a series of 500,250,120 and $60 \mu \mathrm{m}$ mesh sieves. The biomass of each taxonomic group was estimated as ash-free dry weight (AFDW) according to size categories. Algae volume and dry weight were determined, including epiphytes. Densities of epifauna ranged from 502.9 to 2706.6 ind.20 mll as algae volume. The biomass values (326.6 to $1214.4 \mu \mathrm{g} .20 \mathrm{ml}^{-1}$ AFDW) represented a low standing stock. Harpacticoid copepods and their nauplii were the dominant group and also showed the highest biomass values, being represented by larger individuals ( 250 to $120 \mu \mathrm{m})$. Higher values were observed between the end of the summer and the beginning of the fall (March and April), decreasing until winter (July). This variation may be explained by habitat complexity changes, or reproduction of some taxa, as higher meiofaunal densities were found on the $60 \mu \mathrm{m}$ mesh sieve, including high percentages of nauplii.

- Resumo: Este trabalho avalia qualitativa e quantitativamente a meiofauna associada a Sargassum cymosum estimando-se a densidade e biomassa da fauna, assim como uma possível variação temporal. As coletas foram realizadas à nordeste da Praia do Lázaro, Ubatuba $\left(23^{\circ} \mathrm{S}-45^{\circ} \mathrm{W}\right)$, de dez/90 a jul/91. As frondes foram mergulhadas em solução de água e formaldeído, e os organismos em suspensão retidos em uma série de malhas $(500,250,120$ e $60 \mu \mathrm{m})$. Para cada grupo taxonômico foi estimada a biomassa em $\mu \mathrm{g}$ de peso seco livre de cinzas. Como medida de substrato foi determinado o volume e a biomassa em peso seco de alga, incluindo-se as algas epífitas. Os valores de densidade da meiofauna variaram entre 502,9 a 2706,6 ind $20 \mathrm{ml}^{-1}$ de alga. A biomassa estimada por sua vez apresentou valores baixos, entre 326,6 a $1214,4 \mu \mathrm{g} .20 \mathrm{ml}^{-1}$ peso seco livre de cinzas. Copepoda Harpacticoida e seus náuplios foram dominantes numericamente e em relação à biomassa. Os valores de densidade e biomassa da meiofauna foram altos no final do verão (março) e início do outono (abril), e diminuíram gradativamente até o início do inverno (julho). Esta variação pode ser explicada por mudanças na complexidade do habitat ou, ainda, devido ao período reprodutivo de alguns táxons, já que a maior quantidade de meiofauna ocorreu na malha de $60 \mu \mathrm{m}$ (náuplios).

- Descriptors: Meiofauna, Phytal, Sargassum, Ubatuba, São Paulo.

- Descritores: Meiofauna, Fital, Sargassum, Ubatuba, São Paulo. 


\section{Introduction}

The phytal meiofauna consists of predictably dominant forms, such as representatives of the Nematoda, Copepoda, Ostracoda, Acari, Turbellaria, Oligochaeta, Rotifera, Tardigrada, Polychaeta, Kinorhyncha and Gnathostomulida. Generally the former four taxa represent slightly more than $98 \%$ of the whole community (Hicks, 1985). Although the meiofauna shows lower values of biomass than the macrofauna on macroalgae, it exceeds the macrofauna numerically and contributes with about $25 \%$ of the total secondary production, thus constituting an important component (Gibbons \& Griffiths, 1986).

Invertebrates occupy a variety of microhabitats on macroalgae, such as the surface of leaves, the base of the fronds and the interstices of ramifications, where silt, clay and detritus accumulate. The meiofauna can attain higher densities on algae with a complex surface morphology, which facilitates the deposition of sediments and detritus, while lower densities are observed on algae living on exposed rocky shores, with a reduced morphological structure (Hicks, 1980).

The seasonal fluctuation of populations associated with the algae is related to variations in water temperature, the growth cycles of the algae (Mukai, 1971; Kito, 1975; 1982) and an increase in biomass of epiphytes (Johnson \& Scheibling, 1987; Martin-Smith, 1993; Jarvis \& Seed, 1996) or can also result either from the periodicity of the reproductive activity or from the availability of food (Hicks, 1977; Johnson \& Scheibling, 1987).
There are no specific studies on meiofauna associated with algae in Brazil, although some studies on macrofauna from Sargassum, such as Montouchet (1979), Tararam \& Wakabara (1981) and Tanaka \& Leite (1998), include part of the larger meiofauna. Masunari $(1982,1983)$ used a mesh size small enough to collect both the macro and meiofauna of Amphiroa but did not distinguish between the two categories.

Sargassum forms extensive coverings close to the lower level of the intertidal zone and also in the shallow subtidal zone on the rocky shores of the southeastern Brazilian coast. On Lázaro Beach, $S$. cymosum var. cymosum is found in the intertidal zone (Paula, 1978; Eston, 1987).

The present study seeks, qualitatively and quantitatively to evaluate the meiofauna associated with Sargassum cymosum C. Agardh, and estimate the density and biomass of the taxa and their temporal variation.

\section{Material and methods}

The samples were collected on the rocky northeastern shore of Lázaro Beach $\left(23^{\circ} \mathrm{S}\right.$ $45^{\circ} \mathrm{W}$ ), in Fortaleza Bay, Ubatuba, São Paulo State (Fig. 1). The rocky shore is moderately exposed to wave action. It is a shallow area, with water depth of about $2 \mathrm{~m}$ (Eston, 1987). Promontories formed by spurs projecting from the base of the mountain chain limit the extension of Lázaro Beach.

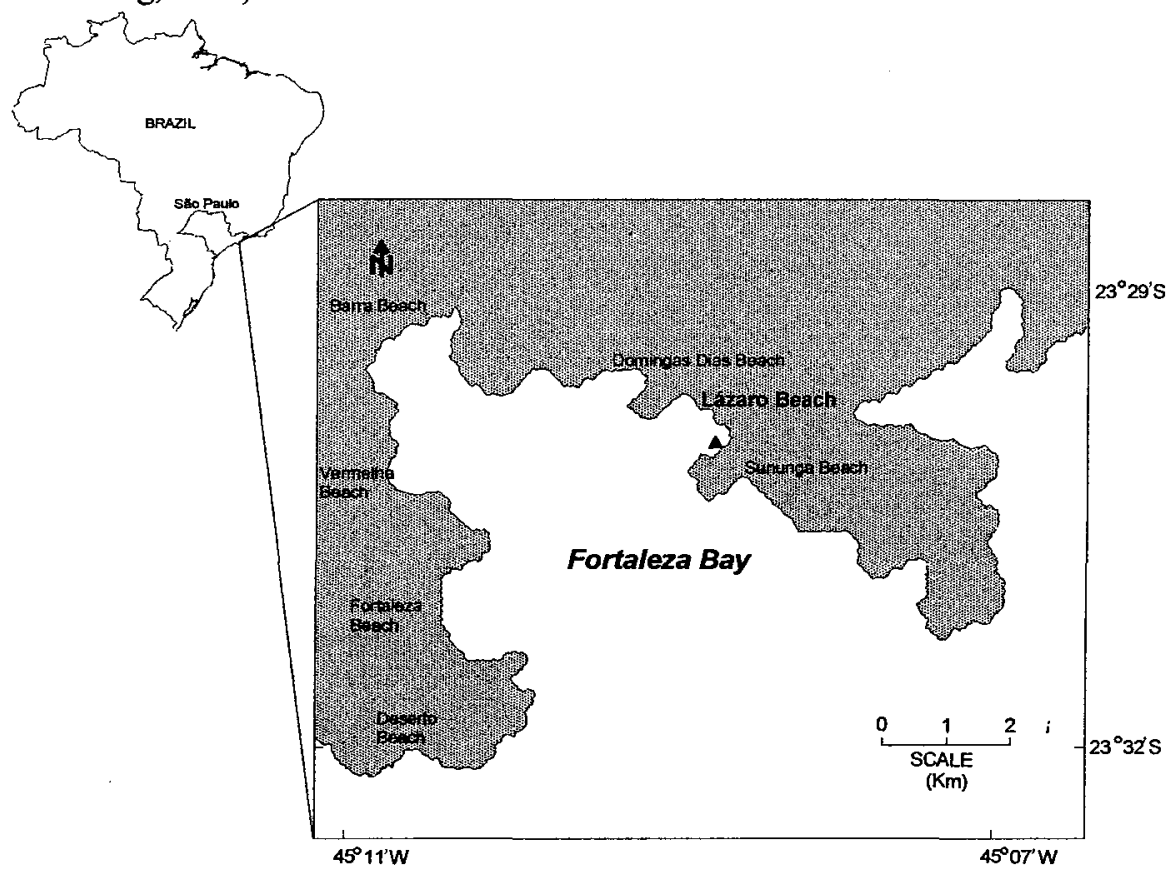

Fig. 1. Map of Lázaro Beach, Ubatuba, SP, showing study site (A). 
Samples were collected at intervals of one to two months during the period from December 1990 to July 1991, in late spring (01/12) and summer (18/01 and 14/03), autumn (15/04 and 30/05) and winter $(26 / 07)$. During each sampling period, 5 individual plants of Sargassum cymosum were collected randomly below the lowest tidal limit (with the fronds submerged) and were immediately put into plastic bags. The algae were washed in pails containing a formaldehyde solution. The solution containing the animals was then sieved through a series of 500,200 , 120 and $60 \mu \mathrm{m}$ mesh size sieves to separate the organisms into different size categories and estimate the biomass (Pfannkuche \& Thiel, 1988). The organisms were fixed in $4 \%$ buffered formaldehyde, stained with Rose Bengal and the taxa identified and counted.

As an estimation of measurement of the available space for the meiofauna, the volume of the algae was determined by displacement in a measuring cylinder. The algal biomass was determined by drying until a constant weight at $60^{\circ} \mathrm{C}$ was attained (Paula, 1978; Montouchet, 1979). Algal volume and biomass also include the epiphytic algae Hypnea, since this algae is impossible to separate from Sargassum. Temperature and salinity of the seawater were measured during the collection.

The biomass of the meiofauna was estimated in terms of $\mu \mathrm{g}$ of ash-free dry weight (AFDW) for each zoological group and separated into categories by size, using the individual mean weights (Corbisier, 1993).

Harpacticoid copepods were identified to genus. One hundred of each sample were randomly separated using a Dolphus plate. For identification purposes the studies of Lang (1948, 1965a, 1965b), Wells (1976), Coull (1977) and Huys et al. (1996) were used.

The data were standardized for $20 \mathrm{ml}$ of algae, which represents the smallest volume collected. Density is expressed as number of individuals per 20 $\mathrm{ml}$ of algae and biomass as $\mu \mathrm{g}$ per $20 \mathrm{ml}$ of algae. The data were transformed into $\log (\mathrm{x}+1)$ to normalize the frequency distribution and the homogeneity of the variances was checked by Bartlett's test (Zar, 1996). Differences in total meiofauna and in the density and biomass of the main groups were investigated from month to month using one-way variance analysis (ANOVA) and Tukey's a posteriori multiple comparison (Zar, 1996).

Density and biomass of total meiofauna, Copepoda nauplii, Copepoda juveniles and adults, and Nematoda data were analysed by non-metric multidimensional scaling ordination (NMS) (Kruskal \& Wish, 1978) using double square root transformations with the Bray-Curtis similarity index (Clarke \& Green, 1988) and Persons r correlation between variables (density and biomass) and the axes.
Enviromental variables (water temperature and salinity, algae volume and biomass) were superimposed on the 2-D NMS configurations to provide visual correlations (Field et al., 1982).

\section{Results}

\section{Environmental data}

The lowest salinity value measured was 32.2 , occurring in January, when a high precipitation index was observed during the sampling day and the previous day. A maximum salinity of 34.9 was measured in December. Sea water temperature was lowest in July $\left(22.3^{\circ} \mathrm{C}\right)$ and highest in March and April $\left(28.5^{\circ} \mathrm{C}\right)($ Table 1$)$.

Table 1. Environmental data from Lázaro Beach. Ubatuba.

\begin{tabular}{c|c|c}
\hline Sampling date & Salinity (\%o) & $\begin{array}{c}\text { Temperature } \\
\left({ }^{\circ} \mathbf{C}\right)\end{array}$ \\
\hline $01 / 12 / 90$ & 34.9 & 27.0 \\
\hline $18 / 01 / 91$ & 32.2 & 26.1 \\
\hline $14 / 03 / 91$ & 34.3 & 28.5 \\
\hline $15 / 04 / 91$ & 34.4 & 28.5 \\
\hline $30 / 05 / 91$ & 34.6 & 24.6 \\
\hline $26 / 07 / 91$ & 33.3 & 22.3 \\
\hline
\end{tabular}

\section{Sargassum cymosum}

The average biomass of the algae varied from $6.9 \mathrm{~g}$ dry weight $( \pm 1.9)$ in March to $13.9 \mathrm{~g}$ dry weight $( \pm 5.1)$ in December, which corresponds to months of minimum and maximum variation in volume, respectively (Table 2 ).

\section{Meiofauna}

The lowest density of the meiofauna was observed in December, with an average of 502.9 ind. $20 \mathrm{ml}^{-1}( \pm 269.3)$, whereas the highest average occured in March with 2706.6 ind. $20 \mathrm{ml}^{-1}$ $( \pm 2194.6) \quad$ (Fig. 2). The estimated biomass was lowest in July, with an average of $326.6 \mu \mathrm{g} 20$ $\mathrm{ml}^{-1}( \pm 190.4)$, and highest in March, with an average of $1214.4 \mu \mathrm{g} 20 \mathrm{ml}^{-1}( \pm 779.5)$ (Fig. 2). ANOVA results show significant differences in density and biomass of the meiofauna as between months (Tables 3 and 4). 
Table 2. Volume (V, $\mathrm{ml})$ and biomass (B, g dry weight) of Sargassum cymosum on Lázaro Beach, Ubatuba.

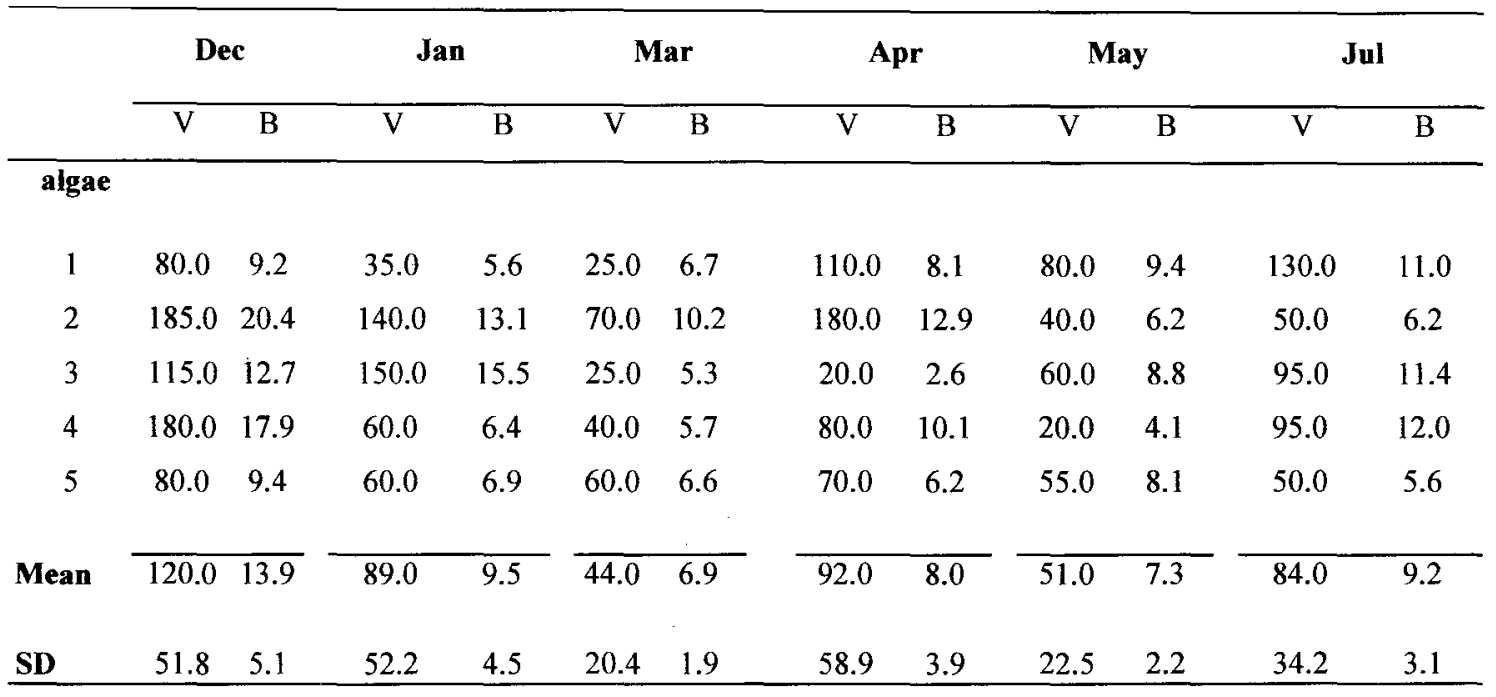

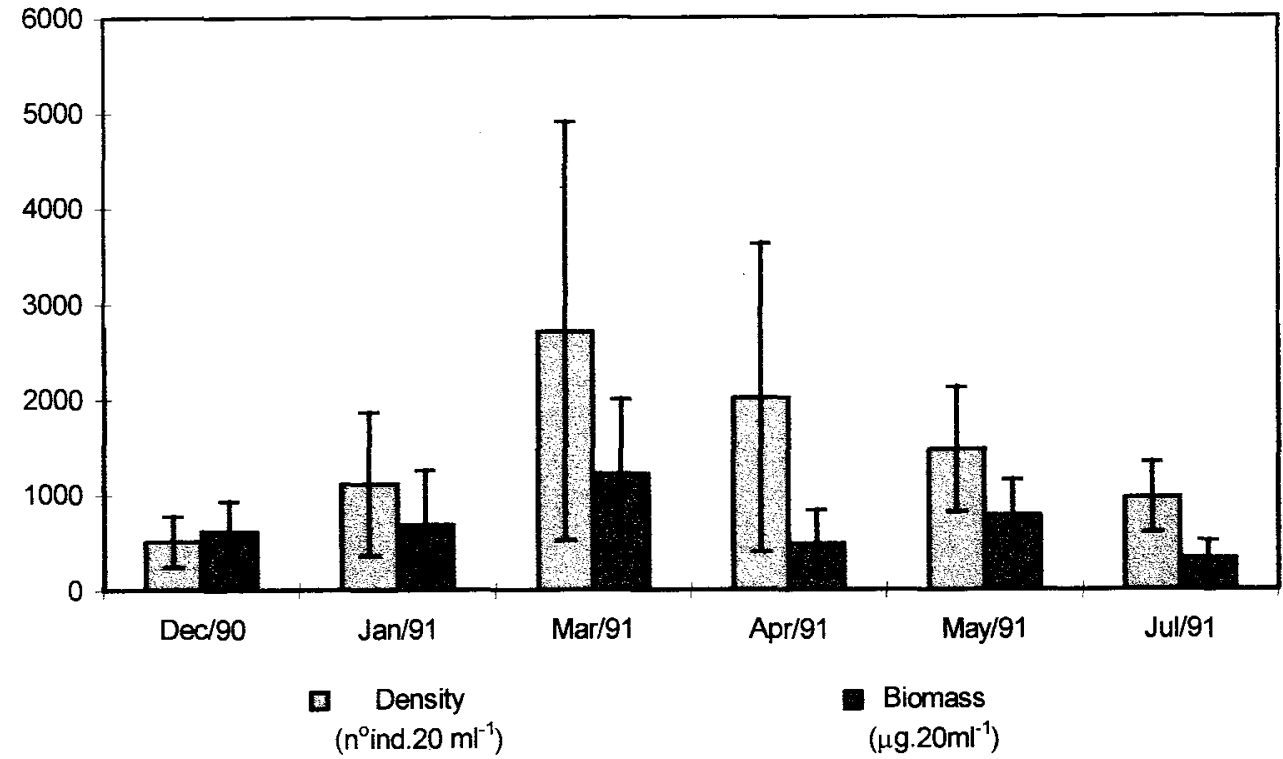

Fig. 2. Meiofauna mean density $\left(\mathrm{n}^{0}\right.$ ind.20 $\left.\mathrm{ml}^{-1}\right)$ and biomass $\left(\mu \mathrm{g}\right.$ of ash-free dry weight. $\left.20 \mathrm{ml}^{-1}\right)$ on Sargassum cymosum.

Values found for the total density of the meiofauna show that in December (late spring) density was lowest, distinguishing this month from March and April (summer and early autumn), when values were higher. Copepod nauplii, the most abundant organisms, followed by adult and juvenile copepods, and Nematoda showed a similar pattern of density variation as well, both having high densities in March (late summer). Some taxa had lowest densities in the spring (December) and early summer (January). Other taxa which showed highest abundance mainly in December and/or March were
Acari, Ostracoda, Gastropoda, Gammaridea and Polychaeta, with lower densities found in April (autumn) or July (winter) (Table 3).

For biomass data, April (early autumn) and July (winter) showed the lowest values, contrasting with March, when the highest values occurred. Copepoda was the most abundant group, with all stages presenting maximum values in March (summer). The ANOVA and the a posteriori comparison results of the biomass of the main groups among the different collections showed the same general groupings as observed for density (Table 4). 
Table 3. One-way analysis of variance (ANOVA) and $a$ posteriori multiple comparison of Tukey $(\mathrm{p}<0.05)$ in relation to total meiofauna and main group densities.

\begin{tabular}{|c|c|c|c|c|c|c|c|c|}
\hline Density & $\mathbf{x}$ & $\mathbf{F}$ & & & Tu & & & \\
\hline Meiofauna & $\begin{array}{c}1459 . \\
6\end{array}$ & 4.52 & Dec & Jul & Jan & May & Apr & Mar \\
\hline $\begin{array}{l}\text { Copepoda } \\
\text { (nauplii) }\end{array}$ & 50.83 & 20.14 & Dec & Jan & Jul & May & Apr & Mar \\
\hline Copepoda & 25.99 & 4.18 & Dec & Jul & Jan & Apr & May & Mar \\
\hline Nematoda & 8.65 & 4.74 & Dec & Jan & Apr & May & Jul & Mar \\
\hline Acari & 4.46 & 5.30 & Apr & Jul & May & Jan & Mar & Dec \\
\hline Ostracoda & 3.71 & 26.90 & $\mathrm{Jul}$ & Apr & May & Jan & Dec & Mar \\
\hline Gastropoda* & 1.52 & 54.25 & Jul & Apr & Jan & Mar & May & Dec \\
\hline Gammaridea* & 1.46 & 3.89 & May & Apr & Jul & Mar & Jan & Dec \\
\hline Polychaeta* & 0.97 & 4.31 & JuI & $\operatorname{Jan}$ & Dec & Apr & May & Mar \\
\hline
\end{tabular}

NMS configuration for the density of the meiofauna taxa studied are shown in Figure 3. The month replicates clustered more or less closely to each other and are arranged in a clear similar sequence (from right to left): December, January-March, May. and April-July, except for March 1, 3 replicates, and the axis 2 where variation is much more pronounced. March 1, 3 replicates were always separate from the remaining months' replicates. The correlation test on the double square root transformed density data indicates that April-July densities were significantly different from March 1,3 , the highest densities, and from December with the smallest densities.

From Figure 4 it is clear that there is no close relationship between the configuration and the natural environmental variables temperature and salinity. There is an inverse correlation mainly with algae volume, and a lesser one with biomass, with the highest volume on the upper side of the configuration.
Table 4. One-way analysis of variance (ANOVA) and $a$ posteriori multiple comparison of Tukey $(\mathrm{p}<0.05)$ in relation to total meiofauna and main group biomasses.

\begin{tabular}{|c|c|c|c|c|c|c|c|c|}
\hline \multirow{2}{*}{$\frac{\text { Biomass }}{\text { Meiofauna }}$} & \multirow{2}{*}{$\begin{array}{c}\mathrm{X} \\
\begin{array}{c}683.2 \\
9\end{array}\end{array}$} & \multirow{2}{*}{$\frac{F}{3.56}$} & \multicolumn{6}{|c|}{ Tukey } \\
\hline & & & Jul & Apr & May & Jan & Dec & Mar \\
\hline $\begin{array}{l}\text { Copepoda } \\
\text { (nauplii) }\end{array}$ & 6.52 & 17.70 & Dec & Jan & $\mathrm{Jul}$ & May & Apr & Mar \\
\hline Copepoda & 43.10 & 4.32 & Dec & Jul & Jan & Apr & May & Mar \\
\hline Nematoda & 4.94 & 3.85 & Jan & Dec & Apr & May & Jul & Mar \\
\hline Acari & 1.14 & 4.74 & Apr & Jul & Jan & May & Mar & Dec \\
\hline Ostracoda & 8.68 & 26.52 & Jul & Apr & May & Jan & Dec & Mar \\
\hline Gastropoda* & 7.72 & 65.34 & Jul & Apr & Jan & Mar & May & Dec \\
\hline Gammaridea* & 15.57 & 3.69 & May & Apr & Jul & Mar & Jan & Dec \\
\hline Polychaeta* & 7.29 & 4.07 & Jul & Jan & Dec & Apr & May & Mar \\
\hline
\end{tabular}

NMS configuration for the total and the meiofaunal taxa biomass studied showed no such clear trend as density. Nevertheless, there is some indication that Copepoda nauplii, Copepoda and Nematoda biomass varied inversely with the volume and biomass of the algae, and the months' replicates cluster according to a pattern similar to that for density mainly as regards March 1, 3 which are distinct from the others, especially from the December-January and April replicates (Figs 5 and 6).

In relation to the size of the organisms, the Copepoda were observed in the greatest numbers in the 250 and $120 \mu \mathrm{m}$ meshes, except in April, when they were more abundant in the 120 and $60 \mu \mathrm{m}$ meshes (Fig. 7 and Table 5).

Eight genera of Hapacticoid Copepods were identified: Tisbe sp., Ectinossoma sp., Diarthrodes sp., Amphiascus sp., Laophonte sp., Scutellidium sp., Harpacticus sp. and Tegastes sp. The Tisbe and Ectinossoma genera were the most abundant. 

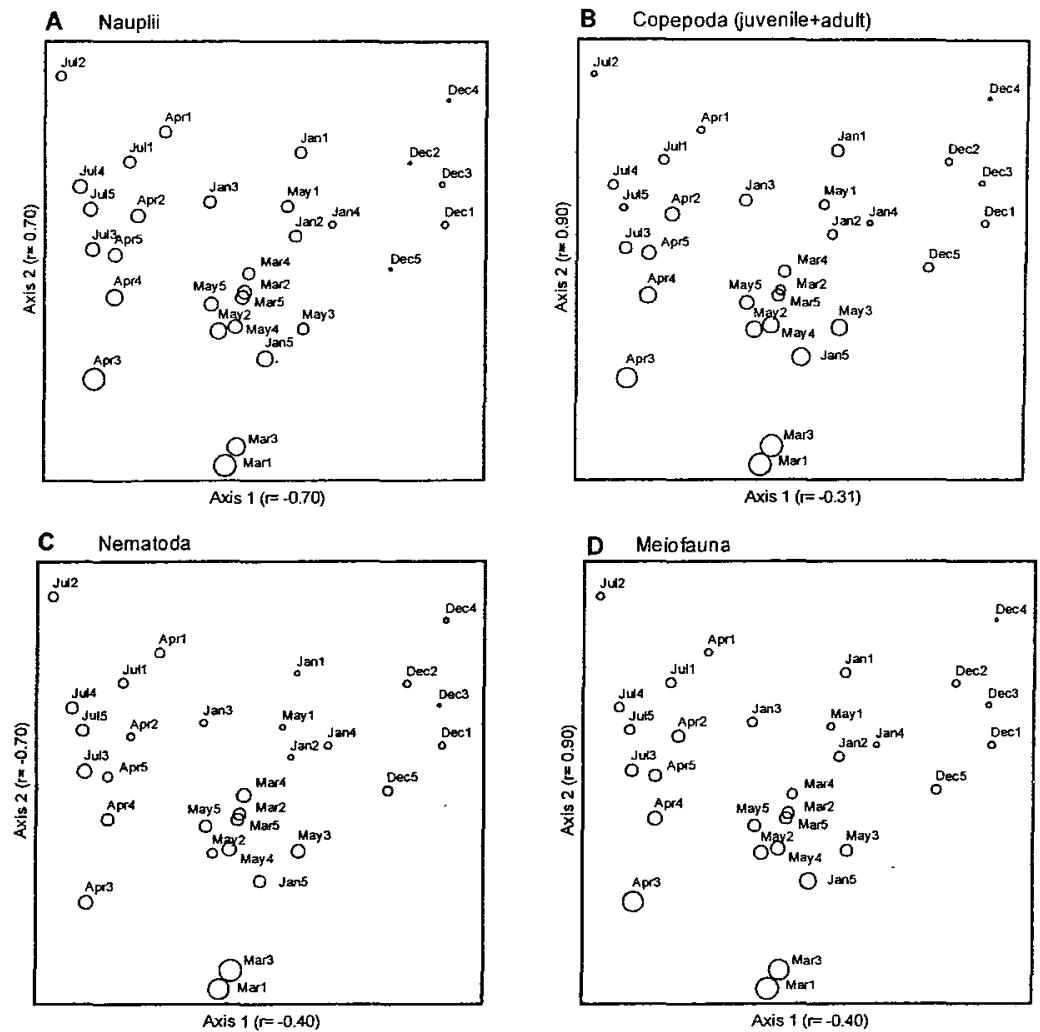

Fig. 3. Two dimensional NMS ordinations of the double square-root transformed density data: Copepoda nauplii (A), Copepoda juveniles plus adults (B), Nematoda (C) and total meiofauna (D) on Sargassum in December/90, January, March, April, May and July/91. The scaling of symbols on these diagrams can be deduced from tables 1 and 2 .
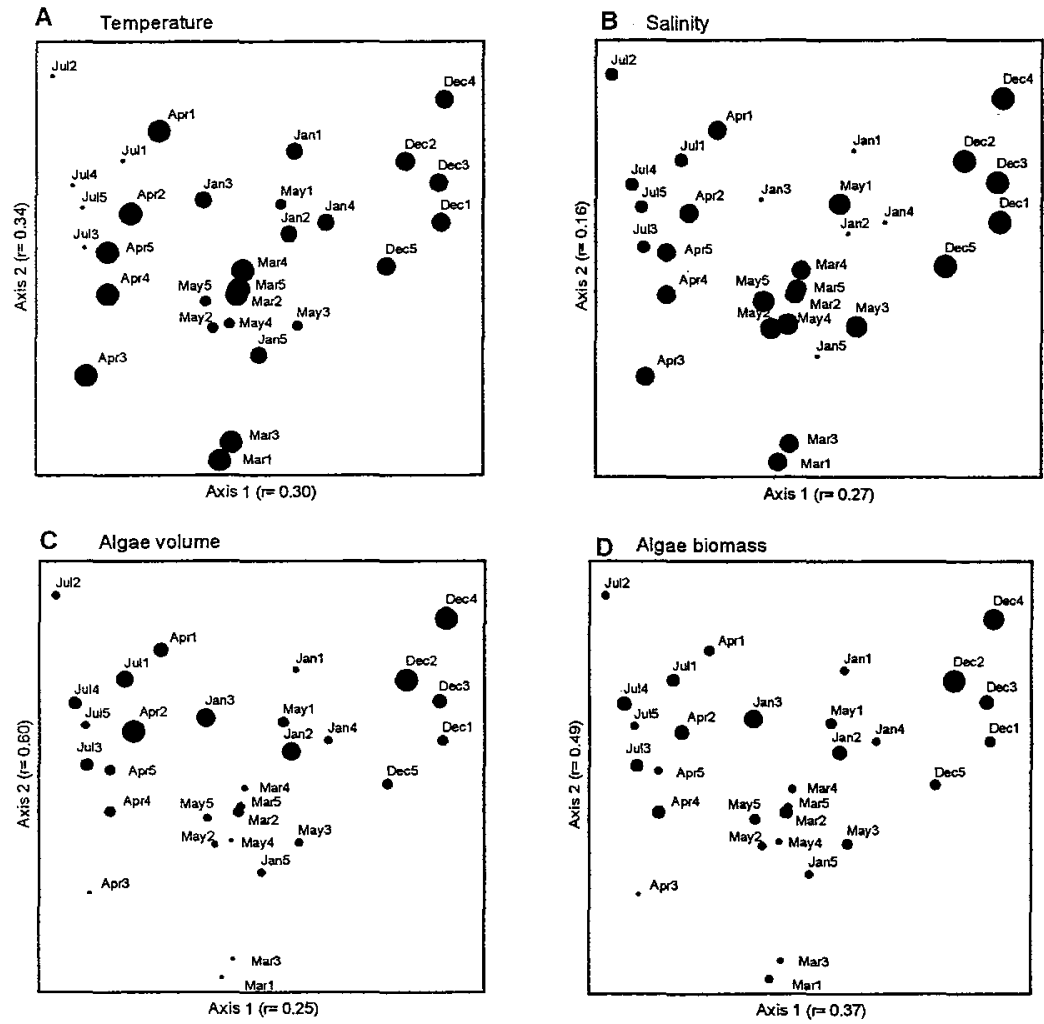

Fig. 4. Two dimensional NMS configuration with symbols representing values of enviromental variables superimposed on density data of meiofauna: A - Temperature; B - Salinity; C - Algae volume; D - Algae biomass. The scaling of symbols on these diagrams can be deduced from tables 1 and 2. 

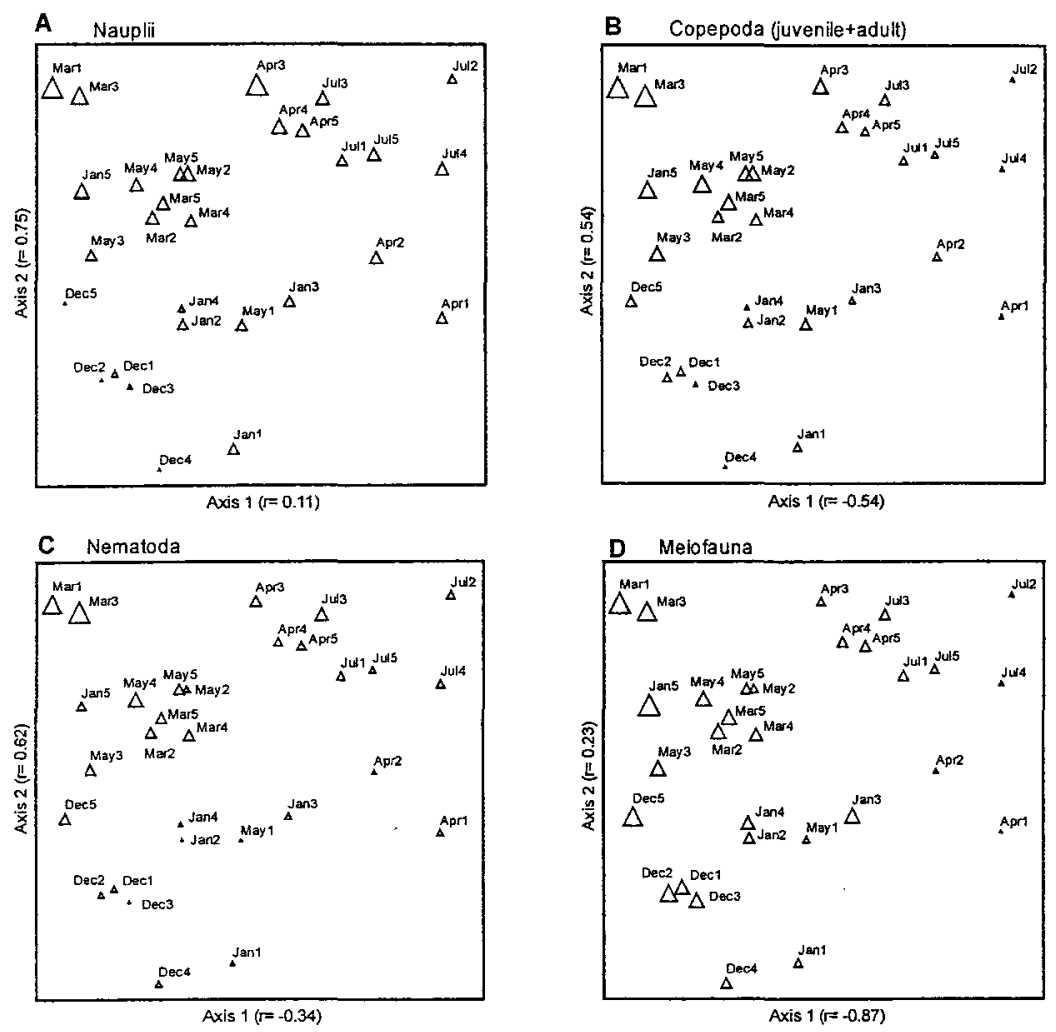

rig. 5. Two dimensional NMS ordinations of the double square-root transformed biomass data: Copepoda nauplii (A), Copepoda juveniles plus adults (B), Nematoda (C) and total meiofauna (D) on Sargassum in December/90, January, March, April, May and July/91. The scaling of symbols on these diagrams can be deduced from tables 1 and 2 .
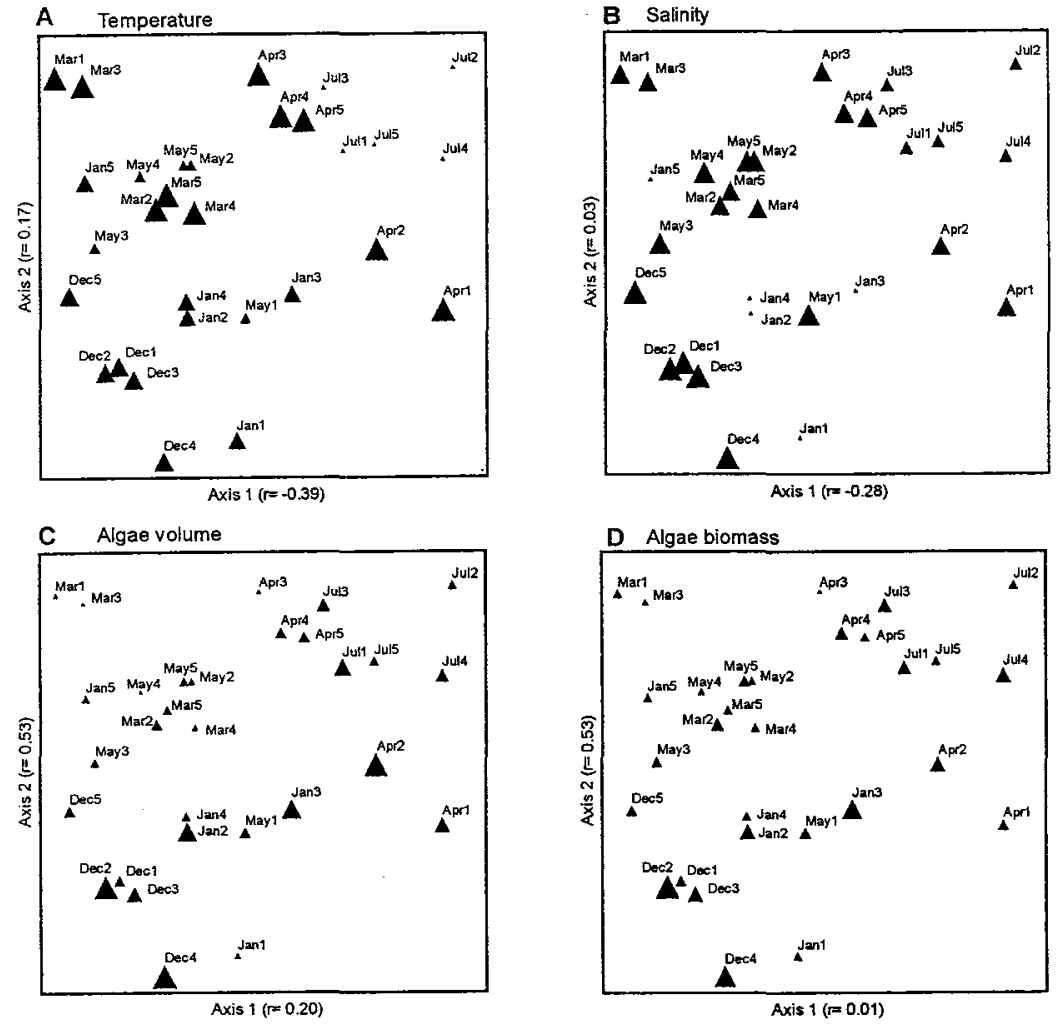

Fig. 6. Two dimensional NMS configuration with symbols representing values of enviromental variables superimposed on biomass data of meiofauna: A - Temperature; B - Salinity; C - Algae volume; D - Algae biomass. The scaling of symbols on these diagrams can be deduced from tables 1 and 2 . 

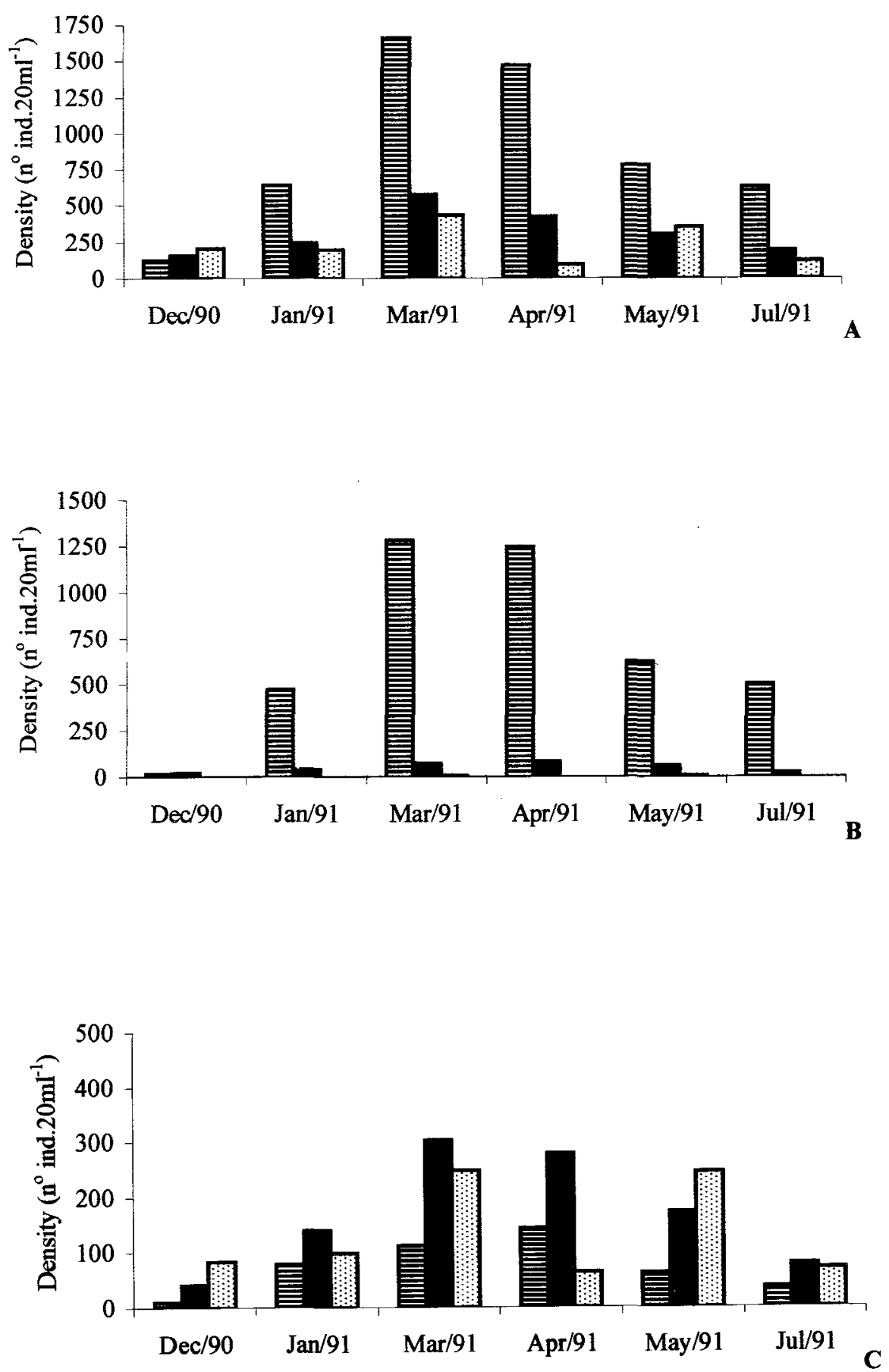

\section{国 $60 \mu \mathrm{m} \quad 120 \mu \mathrm{m} \quad 250 \mu \mathrm{m}$}

Fig. 7. Copepoda nauplii (A), Copepoda juveniles plus adults (B) and total meiofauna densities data (C) retained in 60, 120 e $250 \mu \mathrm{m}$ meshes, in the months sampled. 
Table 5. Average densities ( $\mathrm{n}^{\circ}$ ind. $20 \mathrm{ml}^{-1}$ ) of the meiofauna taxa in the various sieves, during the study.

\begin{tabular}{|c|c|c|c|c|c|c|c|c|c|c|c|c|c|c|c|c|c|c|}
\hline \multirow[b]{2}{*}{ Sieve $(\square \mathbf{m})$} & \multicolumn{3}{|c|}{$\mathrm{Dec} / 90$} & \multicolumn{3}{|c|}{ Jan/91 } & \multicolumn{3}{|c|}{ Mar/91 } & \multicolumn{3}{|c|}{ Apr/91 } & \multicolumn{3}{|c|}{ May/91 } & \multicolumn{3}{|c|}{ Jul/91 } \\
\hline & 250 & 120 & 60 & 250 & 120 & 60 & 250 & 120 & 60 & 250 & 120 & 60 & 250 & 120 & 60 & 250 & 120 & 60 \\
\hline \multicolumn{19}{|l|}{ Taxa } \\
\hline $\begin{array}{l}\text { Copepoda } \\
\text { (nauplii) }\end{array}$ & 1.1 & 21.1 & 15.0 & 0.2 & 41.5 & 471.5 & 5.4 & 69.2 & 1284.3 & 0.1 & 80.8 & 1247.0 & 2.7 & 57.4 & 625.0 & 0.8 & 26.1 & 502.5 \\
\hline Copepoda & 84.0 & 42.0 & 10.9 & 99.6 & 140.5 & 80.2 & 247.6 & 302.6 & 112.9 & 64.5 & 278.0 & 142.7 & 245.8 & 173.3 & 63.4 & 71.3 & 79.6 & 37.2 \\
\hline Nematoda & 7.0 & 14.3 & 16.5 & 4.2 & 10.0 & 34.5 & 78.4 & 114.3 & 170.2 & 8.2 & 23.3 & 56.6 & 31.9 & 27.1 & 50.3 & 11.1 & 36.6 & 62.8 \\
\hline Acarii & 31.9 & 45.7 & 27.6 & 15.6 & 26.0 & 16.6 & 27.6 & 38.8 & 29.1 & 4.6 & 9.9 & 2.5 & 23.2 & 18.6 & 9.5 & 10.6 & 27.0 & 25.6 \\
\hline Ostracoda & 17.4 & 16.5 & 42.4 & 11.8 & 18.6 & 36.2 & 11.4 & 29.8 & 53.7 & 1.6 & 8.2 & 23.4 & 9.9 & 13.5 & 25.0 & 0.4 & 1.1 & 3.9 \\
\hline Gastropoda & 17.0 & 17.9 & 8.9 & 16.0 & 4.0 & 0.5 & 16.3 & 10.8 & 4.8 & & 0.1 & & 19.4 & 12.0 & 5.2 & & & \\
\hline Gammaridea & 41.3 & 0.1 & 0.2 & 39.0 & 2.0 & 0.1 & 15.0 & 2.6 & 0.4 & 8.8 & & & 5.6 & 0.1 & & 12.2 & 0.4 & \\
\hline Polychaeta & 6.5 & 1.7 & 0.1 & 7.7 & 1.6 & & 32.0 & 3.4 & 0.1 & 6.3 & 5.1 & 0.1 & 12.8 & 3.3 & & 3.0 & 1.4 & 0.1 \\
\hline Total & 206.7 & 159.8 & 128.4 & 194.6 & 254.4 & 640.9 & 436.1 & 574.4 & 1659.1 & 95.8 & 421.9 & 1476.1 & 353.5 & 305.8 & 780.3 & 121.0 & 192.1 & 635.7 \\
\hline
\end{tabular}

\section{Discussion}

The comparison of studies analyzing the structure of meiofaunal communities associated with macroalgae is hindered by the lack of uniformity as regards the way in which macroalgae are quantified. Some works calculate the number of individuals per wet weight or dry weight of algae; others by the number of individuals per algae volume or per surface area of the rock. The latter method suffers from the problem of the algae size, which has very different characteristics in the third dimension. The dry weight of the algae or the volume gives a good indication of the space available for the meiofauna.

The meiofauna density observed in the Sargassum of Lázaro Beach is within the values found on other algae. In Brazil, studies of the phytal communities of Sargassum were about macrofauna and took into account only a part of the meiofauna, which makes comparisons difficult, but the values were lower than those obtained in this present study (Table 6).

In biomass terms, the variation observed in the present study ranges from 0.03 to $0.12 \mathrm{~g} \mathrm{AFDW}$ $\mathrm{m}^{-2}$, while in South Africa the biomass of the meiofauna in several intertidal macroalgae ranges from $0.01 \mathrm{~g}$ to $8.5 \mathrm{~g}$ dry weight $\mathrm{m}^{-2}$ (Gibbons \& Griffiths, 1986). Copepoda represented $43 \%$ of the total meiofauna biomass, followed by Ostracoda, nauplii of Copepoda and Nematoda. Copepoda (adults and juveniles) were the most numerous because, besides constituting the second group in density terms, they were relatively large in size being present in greatest numbers in the 250 and $120 \mu \mathrm{m}$ meshes.

The composition of the meiofauna is the result of the various characteristics of the habitat, such as the shape and texture of the stalks of the plants, the interstices, the accumulation of sediment and detritus, the quantity of epiphytas, the degree of protection from the waves and dessication (Muralikrishnamurty, 1983; Preston \& Moore, 1988). The large number of harpacticoids is correlated with the low silt-clay texture and detritus retained in the algal substratum (Mukai, 1971; Boaden, 1996). Besides, all the harpacticoid genera found in $S$. cymosum are characteristic of the phytal habitat (Tisbe sp., Ectinossoma sp., Diarthrodes sp., Amphiascus sp., Laophonte sp., Scutellidium sp., Harpacticus sp. and Tegastes sp.), indicating a smaller amount of sediment on the algae (Hicks, 1985). These genera are adapted to a free-swimming existence and also show a dorso-ventrally depressed body (Scutellidium sp.) to stick to the substratum, or present the first differentiated pair of jaws and maxillipeds sufficiently well developed to hold on to the algal substratum (Laophonte sp) (Hicks \& Coull, 1983).

The meiofauna showed a seasonal trend in density and estimated biomass. The abundance was highest in late summer (March) and early autumn (April), decreasing gradually until the winter (July). However, seasonal changes were not clear for individual taxa. Two groups can be distinguished, one including nauplii and adults of Copepoda, Nematoda, Ostracoda and Polychaeta, with its highest density in late summer (March), and another including the Acari, Gastropoda and Gammaridea with its highest density in late spring (December). To confirm the observed seasonal trend in the densities of the main taxa specific further study of these taxa is necessary which has so far been impossible due to a lack of specialists in some of the taxa (Jarvis \& Seed, 1996). 
Table 6. Phytal meiofauna studies.

\begin{tabular}{|c|c|c|c|c|c|}
\hline AUTHOR & LOCATION & & DENSITY & DOMINA & T TAXA \\
\hline Hagerman, 1966 & Denmark & Fucus & $5.2-173.9$ & ind. $g^{-1}$ wet weight & $\begin{array}{l}\text { Ostracods. } \\
\text { Copepods }\end{array}$ \\
\hline Mukai, $1971^{*}$ & Japan & Sargassum & $100-470$ & ind. $g^{-1}$ wet weight & Copepods \\
\hline Kito, 1975* & Japan & Sargassum & $20.7-726.5$ & ind. $\mathrm{g}^{-1}$ wet weight & Copepods \\
\hline Montouchet, $1979^{*}$ & São Paulo, Brazil & Sargassum & 1.46 & ind. $\mathrm{m}^{-1}$ & \\
\hline Tararam \& Wakabara, 1981* & Brazil & Sargassum & $6.94-7.34$ & ind. $g^{-1}$ wet weight & \\
\hline Coull et al., 1983 & South Carolina, U.S.A. & 4 spp. Algae & $22-1345$ & ind. $g^{-1}$ dry weight & Copepods \\
\hline \multirow[t]{2}{*}{ Jonhson \& Scheibling, 1987} & Canada & Ascophylum nodosum & $409-1.9 \times 10^{5}$ & ind. $m^{-2}$ & Copepods \\
\hline & & Fucus vesiculosus & $436-8.2 \times 10^{5}$ & ind. $m^{-2}$ & Copepods \\
\hline \multirow[t]{3}{*}{ Present study } & São Paulo, Brazil & Sargassum cymosum & $193-1041$ & ind. $g^{-1}$ dry weight & Copepods \\
\hline & & & $25-135$ & ind. $m l^{-1}$ & \\
\hline & & & $2.9 \times 10^{5}-6.6 \times 10^{5}$ & ind. $\mathrm{m}^{-2}$ & \\
\hline
\end{tabular}

* These studies included the macrofauna

Table modified from Hicks \& Coull (1983) and Coull et al. (1983)

Acari, Gastropoda and Gammaridea had the highest biomass in late spring and in summer (December and January). The Gastropoda, Gammaridea, Polychaeta, Isopoda and Bivalvia contributed with $52 \%$ of the biomass in December and $44 \%$ in January (summer). These groups constitute the temporary meiofauna, juveniles which move into macrofauna as they grow (Gibbons \& Griffiths, 1986). The results do not agree with those found by Gibbons \& Griffiths (1986), who reported a lower contribution of the same groups in the summer $(6.7 \%)$ and winter $(11 \%)$.

The density of the meiofauna showed an inverse relationship with the biomass and algal volume and a positive relationship seems to be only true for the Acari, Gastropoda and Gammaridea. In Japan the seasonal variations of the meiofauna were affected by the biomass of the alga Sargassum, a high density of the meiofauna occurring in the winter and early autumn, coinciding with the growth of Sargassum and consequent increase in algal biomass (Mukai, 1971). However, the populations of $S$. cymosum of Ubatuba are perennial, with their holdfasts and main stems persisting throughout the year. Their primary lateral branches are constantly in development, being continually renewed (Paula \& Oliveira, 1980).

The biomass and volume of Sargassum measured in this project include the epiphytic algae.
The presence of epiphytic algae promotes an increase in the complexity of the habitat. The quantity of epiphytes present generally introduces seasonal variation, and their high abundance in general corresponds to periods of low algal biomass (Jonhson \& Scheibleing, 1987; Martin-Smith, 1993; Jarvis \& Seed, 1996). In Ubatuba, the presence of epiphytes in Sargassum is common during the summer and in early autumn, and is related to the larger number of mature branches of the algae (Eston, 1987). This suggests that epiphyte abundance and its seasonal changes influence the meiofauna of $S$. cymosum.

Another hypothesis regarding the higher density of the meiofauna may be linked to the reproductive period of some species and is reflected in the higher density observed in the summer owing to the large number of organisms retained in the 60 $\mu \mathrm{m}$ mesh. Among these, the nauplii of Harpacticoida were the most abundant, indicating the predominance of young stages over the adult meiofauna. In Hagerman's study (1966) the greatest microfauna density associated with Fucus serratus was also correlated with the reproductive period of many species in the summer.

The high density found in January and March (summer) may also be, in part, the result of climatological conditions generating high food availability. On the coast of São Paulo State the rainfall is more frequent during the summer (Pereira, 
1994), causing an increase in the input of fine material and organic matter from the forest adjacent to the rocky shore.

\section{Acknowledgements}

We thank Dra. Tagea K. S. Björnberg, Dr. Paulo J. P. dos Santos and Dra. Lília P. Souza-Santos for their collaboration in this study. Coordenação de Aperfeiçoamento de Pessoal de Nível Superior (CAPES) provided schollarships to R. Curvelo. Two anonymous referees for their comments.

\section{References}

Boaden, P. J. S. 1996. Habitat provision for meiofauna by Fucus serratus epifauna with particular data on the flatworm Monocelis lineata. Mar. Ecol., 17(1-3):67-75.

Clarke, K. R. \& Green, R. H. 1988. Statistical design and analysis for a "biological effects" study. Mar. Ecol.-Prog. Ser., 46(1-3):213-226.

Corbisier, T. N. 1993. Meiofauna da plataforma continental interna do litoral norte de São Paulo - verão/89. Publção esp. Inst. oceanogr., S Paulo, (10):123-135.

Coull, B. C. 1977. Marine flora and fauna of the northeastern United States. Copepoda: Harpacticoida. NOAA Technical Report. NHFS Circular, (399): 1-48.

Eston, V. R. de. 1987. Avaliação experimental da dominância ecológica em uma comunidade de macroalgas do infralitoral rochoso (Ubatuba, SP, Brasil). Tese de doutorado. Universidade de São Paulo, Instituto Oceanográfico. $2 v$.

Field, J. G. I.; Clarke, K. R. \& Warwick, R. M. 1982. A practical strategy for analysing multispecies distribution patterns. Mar. Ecol. Prog. Ser., 8(1):37-52.

Gibbons, M. J. \& Griffiths, C. L. 1986. A comparison of macrofaunal and meiofaunal distribution and standing stock across a rocky shore, with an estimate of their productivities. Mar. Biol., 93(2):181-188.

Hagerman, L. 1966. The macro- and microfauna associated with Fucus serratus L., with some ecological remarks. Ophelia, 3:1-43.
Hicks, G. R. F. 1977. Observations on substrate preference of marine phytal harpacticoids (Copepoda). Hydrobiologia, 56(1):7-9.

Hicks, G. R. F. 1980. Structure of phytal harpacticoid copepod assemblages and the influence of habitat complexity and turbidity. J. expl mar. Biol. Ecol., 44(2-3):157-192.

Hicks, G. R. F. 1985. Meiofauna associated with rocky shore algae. In: Moore, P. G. \& Seed, R. The ecology of rocky coasts. London, Hodder and Stoughton. p. 36-56.

Hicks, G. R. F. \& Coull, B. C. 1983. The ecology of marine meiobenthic Harpacticoid Copepods. Oceanogr. mar. Biol. a. Rev., 21:67-175.

Huys, R.; Gee, M. J.; Moore, C. G. \& Hamond, R. 1996. Marine and Brackish water harpacticoid Copepods - Part 1. In: Kermack, D. M.; Barnes, R. S. K.; Crothers, J. H., eds. Synopses of the British fauna (new series). $.353 \mathrm{p}$.

Jarvis, S. C. \& Seed, R. 1996. The meiofauna of Ascophyllum nodosum (L.) Le Jolis: characterization of the assemblages associated with two common epiphytes. J. expl. mar. Biol. Ecol., 199(2):249-267.

Johnson, S. C. \& Scheibling, R. E. 1987. Structure and dynamics of epifaunal assemblages on intertidal macroalgae Ascophyllum nodosum and Fucus vesiculosus in Nova Scotia, Canada. Mar. Ecol.-Prog. Ser., 37(2-3):209-227.

Kito, K. 1975. Preliminary report on the phytal animals in the Sargassum confusum region in Oshoro Bay, Hokkaido. J. Fac. Sci. Hokkaido Univ., Ser. VI, Zool., 20 (1):141-158.

Kito, K. 1982. Phytal marine nematode assemblage on Sargassum confusum Agardh with reference to the structure and seasonal fluctuations. J. Fac. Sci. Hokkaido Univ., Ser. VI, Zool., 23(1):143-161.

Kruskal, J. B. \& Wish, M. 1978. Multidimensional scaling. Beverly Hills Sage Publications. 93p.

Lang, K. 1948. Monographie der Harpacticiden. Lund, Hakan Ohlsson's Boktryckeri. 2v.

Lang, K. 1965a. Copepoda Harpacticoida aus dem Küstengrundwasser dicht bei dem AsköLaboratotium (Södermanland, Schweden) Ark. Zool., 18(6):73-83. 
Lang, K. 1965b. Copepoda Harpacticoida from the Californian Pacific coast. K. svenska vetensk. Akad. Handl., 10(2):1-566.

Martin-Smith, K. M. 1993. Abundance of mobile epifauna: the role of habitat complexity and predation by fishes. J. expl mar. Biol. Ecol., 174: 243-260.

Masunari, S. 1982. Organismos do fital de Amphiroa beawvoisii. Lamouroux, 1816 (Rhodophyta: Corallinaceae). I. Autoecologia. Bolm Zool., Univ. S Paulo, 7:57-148.

Masunari, S. 1983. The phytal of the alga Amphiroa fragilissima (Linnaeus) Lamaroux, 1816. Stud. Neotrop. Fauna Env., 18(3):151-161.

Montouchet, P. C. G. 1979. Sur la communauté des animaux vagiles associés à Sargassum cymosum C. Agradh à Ubatuba, État de São Paulo, Brésil. Stud. Neotrop. Fauna Env., 14(1):33-64.

Mukai, H. 1971. The phytal animals on the thalli of Sargassum serratifolium in Sargassum sp. region, with reference to their seasonal fluctuations. Mar. Biol., 8: 170-182.

Muralikrishnamurty, P. V. 1983. Intertidal phytal fauna off Gangavaram, East Coast of India. Indian J. mar. Sci., 12(2):85-89.

Paula, E. J. 1978. Taxonomia, aspectos biológicos e ecológicos do gênero Sargassum (Phaeophyta, Fucales) no litoral do Estado de São Paulo. Dissertação de mestrado. Universidade de São Paulo, Instituto de Biociências. 190 p.

Paula, E. J de \& Oliveira F ${ }^{\mathrm{o}}$, E. C. de 1980. Aspectos fenológicos de duas populações de Sargassum cymosum (Phaeophyta-Fucales) do litoral de São Paulo, Brasil. Bolm Bot., Univ. S Paulo, 8:2139.
Pereira, C. S. 1994. Meteorologia. In: FUNDESPA Fundação de Estudos e Pesquisas Aquáticas. ed. Diagnóstico ambiental oceânico e costeiro das regiões sul e sudeste do Brasil. São Paulo, FUNDESPA, 2:243-243.

Pfannkuche, O. \& Thiel, H. 1988. Sample processing. In: Higgins, R. P. \& Thiel, H. eds Introduction to the study of meiofauna. Washington, Smithsonian Institution Press. p. 134-135.

Preston, A. \& Moore, P. G. 1988. The flora and fauna associated with Cladophora albida (Huds) Kütz. from rockpools on great Cumbrae island, Scotland. Ophelia, 29(3): 169-186.

Tanaka, M. O. \& Leite, F.P.P. 1998. The effect of sieve mesh size on the abundance and composition of macrophyte-associated macrofaunal assemblages. Hydrobiologia, $389(1-3): 21-28$.

Tararam, A. S. \& Wakabara, Y. 1981. The mobile fauna - especially Gammaridea of Sargassum cymosum. Mar. Ecol.-Prog. Ser., 5(2):157-163.

Wells, J. B. J. 1976. Keys to aid in the identification of marine Harpacticoid Copepods. University of Aberdeen, Department of Zoology. 215p.

Zar, J. H. 1996. Biostatistical analysis. $3^{\text {rd }}$. ed. Englewood Cliffs, N. J., Prentice- Hall. $661 \mathrm{p}$.

(Manuscript received 15 March 2000: revised 10 October 2000: accepted 07 December 2000) 